\title{
The Role of Opioids and Alcohol in the Development of Achalasia Type III and Esophagogastric Junction Outflow Obstruction
}

\author{
Ga Hee Kim and Kee Wook Jung* \\ Department of Gastroenterology, University of Ulsan College of Medicine, Asan Medical Center, Asan Digestive Disease Research Institute, \\ Seoul, Korea

\section{Article: Opioid treatment and excessive alcohol consumption are associated with esophagogastric junction disorders Schindler $V$, Runggaldier $D$, Bianca A, et al \\ (J Neurogastroenterol Motil 2019;25:205-211)}

The chronic use of opioids has been an issue in the United States with an increasing rate of use, and even non-cancer patients are on opioid medications, amounting to up to $4 \%$ of adults. ${ }^{1}$ Side effects of opioid-induced bowel dysfunction have been described in most gastrointestinal luminal organs and include delayed gastric emptying as well as prolonged small and large bowel transit. ${ }^{1}$ Symptomatically, these manifest as nausea, vomiting, distension, and constipation. ${ }^{1}$

It has been shown that the acute administration of opiates, such as morphine, in both humans and animals may result in the increased tone of the circular muscle of the intestine. It also increased non-propagating contractions in the colon and small intestine. ${ }^{2,3}$ Endogenously released endorphins interact with opioid receptors to affect sensation, secretion, and motility. ${ }^{4}$ These receptors have complex effects that are both inhibitory and excitatory, mediated by both presynaptic and postsynaptic receptors. ${ }^{2,5}$ These may be presynaptic effects that are especially important for blocking or downregulating cholinergic excitatory pathways. ${ }^{2,5}$ The blockade of these inhibitory neural inputs can occur due to decreased receptor expression due to chronic opiate stimulation and the impaired release of nitric oxide from inhibitory motor neurons, the disinhibition of gastrointestinal muscle activity, the elevation of resting muscle tone, and nonpropulsive motility patterns. ${ }^{4-7}$

The effects of chronic opioid use on esophageal function have been reported recently. ${ }^{1,8-12}$ There are 3 different subtypes of opioid receptors $(\delta, \mu$, and $\kappa)$, and the mu-type opioid receptor is associated with dysphagia or gastroesophageal reflux disease. ${ }^{1}$ In earlier experimental reports, injected morphine increased lower esophageal sphincter (LES) tone in humans. ${ }^{13}$ Moreover, morphine decreased transient LES relaxation in gastroesophageal reflux disease patients. ${ }^{13}$ Moreover, other mu-type opioid agonists, including loperamide, were attempted in gastroesophageal reflux disease patients. ${ }^{14}$ However, recent papers have reported the effects of long-term opioids on esophageal motility in a case series of patients with what appeared to be esophageal dysmotility in patients on chronic opioids. ${ }^{8-10,12}$ Various manometric abnormalities have been reported in dysphagia patients, including impaired LES relaxation, simultaneous distal esophageal contractions, esophagogastric junction outflow

Received: March 6, 2019 Revised: None Accepted: March 14, 2019

(.) This is an Open Access article distributed under the terms of the Creative Commons Attribution Non-Commercial License (http://creativecommons. org/licenses/by-nc/4.0) which permits unrestricted non-commercial use, distribution, and reproduction in any medium, provided the original work is properly cited.

*Correspondence: Kee Wook Jung, MD, PhD, AGAF Department of Gastroenterology, University of Ulsan College of Medicine, Asan Medical Center, Asan Digestive Disease Research Institute, 88 Olympic-ro 43-gil, Songpa-gu, Seoul 05505, Korea Tel: +82-2-3010-3900, Fax: +82-2-3010-6517, E-mail: jung.keewook30@gmail.com 
obstruction (EGJOO), and elevated integrated relaxation pressure. ${ }^{9,10}$ These findings can mimic spastic esophageal dysmotility, such as achalasia type II, III, or EGJOO. ${ }^{10}$ Therefore, a detailed previous medication history should be taken before the initiation of treatment because stopping opioid medication can restore spastic esophageal dysmotility to nearly normal peristalsis. ${ }^{8,10}$

In the retrospective study of Schindler et al. in this issue, ${ }^{15}$ chronic opioid use was associated with EGJOO disorders, like in previous studies. Because of the limitations of retrospective analysis, they could not show the reversal of spastic contractility after the cessation of opioid medication. Interestingly, this study also showed a significant correlation with chronic alcohol abuse. In a limited study based on a human or animal model, excessive alcohol use could mimic EGJOO by interfering with nitric oxide-mediated LES relaxation. ${ }^{16,17}$ This nitric oxide mechanism was also postulated to be a factor in opioid-related esophageal dysmotility disorders. ${ }^{17}$

In conclusion, a detailed medication history should be taken in patients with spastic esophageal dysmotility disorders including alcohol or opioid medications before the initiation of treatment. After the widespread use of invasive treatment including per-oral endoscopic myotomy (POEM), POEM became the optimal treatment of choice even in EGJOO or other spastic esophageal motility disorders, ${ }^{18-20}$ because the cessation of those medications or alcohol could reverse their esophageal dysmotility.

\section{Financial support: None.}

\section{Conflicts of interest: None.}

Author contributions: Ga Hee Kim drafted and edited the manuscript and Kee Wook Jung performed critical revision and final approval of this article.

\section{References}

1. Camilleri M, Lembo A, Katzka DA. Opioids in gastroenterology: treating adverse effects and creating therapeutic benefits. Clin Gastroenterol Hepatol 2017;15:1338-1349.

2. Woods JH, France CP, Medzihradsky F, Smith CB, Winger GD. Evaluation of new compounds for opioid activity annual report (1993). NIDA Res Monogr 1994;140:196-247.

3. Telford GL, Condon RE, Szurszewski JH. Opioid receptors and the initiation of migrating myoelectric complexes in dogs. Am J Physiol
1989;256(1 Pt 1):G72-G77.

4. Holzer P. Opioid receptors in the gastrointestinal tract. Regul Pept 2009;155:11-17.

5. De Luca A, Coupar IM. Insights into opioid action in the intestinal tract. Pharmacol Ther 1996;69:103-115.

6. Wood JD, Galligan JJ. Function of opioids in the enteric nervous system. Neurogastroenterol Motil 2004;(16 suppl 2):17-28.

7. Murray JA, Ledlow A, Launspach J, Evans D, Loveday M, Conklin $\mathrm{JL}$. The effects of recombinant human hemoglobin on esophageal motor functions in humans. Gastroenterology 1995;109:1241-1248.

8. Kraichely RE, Arora AS, Murray JA. Opiate-induced oesophageal dysmotility. Aliment Pharmacol Ther 2010;31:601-606.

9. Ravi K, Murray JA, Geno DM, Katzka DA. Achalasia and chronic opiate use: innocent bystanders or associated conditions? Dis Esophagus 2016;29:15-21.

10. Ratuapli SK, Crowell MD, DiBaise JK, et al. Opioid-induced esophageal dysfunction (OIED) in patients on chronic opioids. Am J Gastroenterol 2015;110:979-984.

11. Jung KW, Myung SJ, Jung HY. A patient with dysphagia associated with opioid medication. J Neurogastroenterol Motil 2012;18:220-221.

12. Jung KW, Kraichely RE, Arora AS, Katzka DA, Romero Y, Murray J. Manometric characteristics of opioid esophageal dysmotility disorder by high-resolution manometry. Gastroenterology 2011;140(suppl 1):S-229.

13. Penagini R, Bianchi PA. Effect of morphine on gastroesophageal reflux and transient lower esophageal sphincter relaxation. Gastroenterology 1997;113:409-414.

14. Allocca M, Mangano M, Colombo P, Penagini R. Effect of loperamide on gastro-oesophageal reflux. Scand J Gastroenterol 2003;38:343-346.

15. Schindler V, Runggaldier D, Bianca A, et al. Opioid treatment and excessive alcohol consumption are associated with esophagogastric junction disorders. J Neurogastroenterol Motil 2019;25:205-211.

16. Keshavarzian A, Polepalle C, Iber FL, Durkin M. Esophageal motor disorder in alcoholics: result of alcoholism or withdrawal? Alcohol Clin Exp Res 1990;14:561-567.

17. Yazir Y, Tugay M, Utkan Z, Utkan T. Effects of chronic ethanol consumption on rat upper gastrointestinal system: functional and histologic findings. Alcohol 2012;46:649-655.

18. Kim GH, Jung KW, Jung HY, et al. Superior clinical outcomes of peroral endoscopic myotomy compared with balloon dilation in all achalasia subtypes. J Gastroenterol Hepatol Published Online First: 29 Jan 2019. doi: 10.1111/jgh.14646.

19. Zaninotto G, Bennett C, Boeckxstaens G, et al. The 2018 ISDE achalasia guidelines. Dis Esophagus 2018;31:1-29.

20. Kahrilas PJ, Bredenoord AJ, Fox M, et al. Advances in the management of oesophageal motility disorders in the era of high-resolution manometry: a focus on achalasia syndromes. Nat Rev Gastroenterol Hepatol 2018;15:323. 